W stużbie tradycji i odnowy liturgicznej. 50 lat Instytutu Liturgicznego w Krakowie (1968-2018), red. P. Nowakowski, J. Mieczkowski, Kraków 2019, s. 161-170.

ISBN 978-83-7438-849-8 (wersja drukowana), ISBN 978-83-7438-850-4 (wersja online) DOI:http://dx.doi.org/10.15633/9788374388504.14

Vojtech Boháč

\title{
Úplná iniciácia v Prešovskej gréckokatolíckej metropolii
}

Katechizmus Katolíckej Cirkvi o svätých iniciačných tajomstvách hovorí, že sú tajomstvami (sviatost’ami) uvádzania do krestanského života, t.j. krstom, birmovaním a Eucharistiou, sa kladú základy celého krestanského života. Na týchto základoch sa stavia duchovná stavba, ktorá smeruje do večnosti. Krestanský Východ tieto sväté tajomstvá slávil aj slávi v jedinom a nedelenom obrade. Napriek tomu ostáva pravdou, že počas dvetisícročnej histórii Cirkvi sa v slávení vyskytli aj odchýlky. Na Druhom vatkikánskom koncile Cirkev vyzvala katolíkov východných obradov k návrato 'starootcovským tradíciám', ak sa od nich odchýlila'.

Śtúdia oboznámi záujemcov o náprave niektorých odchyliek, ktoré sa počas slávenía iniciačných svätých tajomstiev v Prešovskej gréckokatolíckej metropolii vyskytli.

\section{Dvesto rokov Prešovského biskupstva - krátka história}

V roku 2018 uplynie 200 rokov od založenie Prešovského gréckokatolíckeho biskupstva. Prešovské gréckokatolícke biskupstvo bolo kánonicky

I Porov. Orientalium Ecclesiarum, b. 6. Dekrét DVK o Východných katolíckych cirkvách, in: S. Polčin, Dokumenty druhého vatikánskeho koncilu II. Slovenský preklad, Rím 1968, s. 206. 
zriadené bulou 'Relata semper' zo dňa 22. septembra 1818, ktorú vydal pápež Pius VII ${ }^{2}$. Na území biskupstva sa nachádzalo 194 farností a 148987 veriacich ${ }^{3}$.

Zriad’ovacia listina obsahuje konkrétne organizačné smernice, ale liturgické smernice sa v listine nespomínajú. Prvý biskup Gregor Tarkovič zvolal v roku 1821 synodu. 'Ked’že závery z tejto synody sú zatial' nezvestné, možno len predpokladat', že synoda prijala už existujúci bohoslužobný poriadok a slávenia konal podla zabehnutého poriadku z liturgických kníh, ktoré mali k dispozícii`4

Do bohoslužobného poriadku nesporne patria nielen bohoslužobné liturgické knihy, ale aj bohoslužobný liturgický jazyk.

Oficiálnym liturgickým jazykom v novej eparchii bola cirkevná slovančina. Cirkevnoslovanský jazyk ostal spájajúcim materinským jazykom príslušníkov byzantskej liturgie slovanských národov do najnovších čias bez ohl'adu na to, či sú alebo nie sú v spoločenstve s Rímskym stolcom.

Prešovská gréckokatolícka eparchia cirkevnoslovanské liturgické knihy pre svoje potreby až do likvidácie Gréckokatolíckej cirkvi na Ukrajine roku $1946^{5}$ zabezpečovala z L’vova. O štyri roky neskôr sa likvidácia Gréckokatolíckej cirkvi uskutočnila aj v Československu. Likvidačný proces vyvrcholil na tzv. Prešovskom sobore 28. apríla $1950^{6}{ }^{6}$, ked' Gréckokatolícka

2 Porov. P. Šturák, Dejiny Gréckokatolíckej cirkvi v Československu v rokoch 1945-1989, Prešov 1999, s. 27.

3 Porov. B. Bohács, Dr. Russnák Miklós a liturgikus megújulás híve és azeperjesi liturgikus hagyomány őrzője, Nyíregyháza 2004, s. 9.

4 Porov. Bohoslužobný poriadok Mukačevského gréckokatolíckeho biskupstva, z ktorého Prešovská eparchia bola vyčlenená. Bohoslužobný poriadok, až na malé odchýlky, v susedných eparchiách je rovnaký aj v súčasnosti.

5 Gréckokatolícka cirkev na území Ukrajinskej Socialistickej Sovietskej Republiky bola totalitnou mocou zlikvidovaná na nezákonnom sneme zvolanom do L'vova na 8-10. marec 1946. Porov. W. Bobryk, Likvidácia Gréckokatolíckej cirkvi na Ukrajine, v Pol’sku a Československu. Podobnosti a rozdiely in: Cirkev v okovách totalitného režimu, eds. J. Coranič, P. Šturák, J. Koprivnáková, Prešov 2010, s. 323.

6 Porov. J. Coranič, Tzv. Prešovský sobor - vyvrcholenie úsilia totalitnej moci o likvidáciu Gréckokatolíckej cirkvi v Československu, in: Cirkev v okovách totalitného režimu, eds. J. Coranič, P. Šturák, J. Koprivnáková, Prešov 2010, s. 63. 
cirkev prestala existovat' a verejne a oficiálne pôsobit'. Obnovenie a zlegalizovanie obmedzenej činnosti Gréckokatolíckej cirkvi sa udialo v roku 1968, vládnym nariadením č. $70^{7}$. Celkom slobodný vývoj sa pre Gréckokatolícku cirkev začal až od tzv. nežnej revolúcie v roku 1989 až po súčasnost'.

V roku 1968 prešovský ordinár v rámci svojho biskupstva mal jurisdikciu nad gréckokatolíkmi v celom Československu. Po vzniku samostatnej Slovenskej republiky a Českej republiky (1993) Svätý stolec v roku 1995 vyčlenil z územia a spod jurisdikcie Prešovskej eparchie Pražský apoštolský exarchát, ktorý zaberá územie celej Českej republiky . Svätý stolec v roku 1997 vyčlenil z územia a jurisdikcie Prešovskej eparchie Košický apoštolský exarchát, ktorý zaberá územie Košického samosprávneho kraja9. Dňa 30. januára 2008 Svätý stolec zriadil Bratislavské gréckokatolícke biskupstvo, Košický apoštolský exarchát povýšil na eparchiu, Prešovskú eparchiu povýšil na archieparchiu, ktorá zaberá územie Prešovského samosprávneho kraja a zriadil Prešovskú gréckokatolícku metropoliu 'sui iuris ${ }^{10}$. Metropolia má svoju pôsobnost̉ na celom území Slovenska. Celá Prešovská gréckokatolícka metropolia používa liturgické knihy rovnakého pôvodu. Naše skúmanie slávenia iniciácie v liturgických knihách bude tak jednotné a praktické.

\section{Iniciácia v starých trebnikoch z územia Prešovskej eparchie}

Vznikom novej Prešovskej eparchie, sláveniach sa pokračovalo z liturgických kníh, ktoré mali k dispozícii aj do ustanovenia nového biskupstva. K nepostrádatel’ným liturgickým knihám v každom chráme patrí evanjeliár, apoštolár, žaltár, liturgikon, pôstna a kvetná triod’. Slávenie svätých tajomstiev v byzantskom obrade sa koná z liturgickej knihy s názvom ‘trebnik ${ }^{\prime 11}$. Vo vlastníctve Gréckokatolíckeho Arcibiskupského úradu v Prešove sú dva

7 Porov. Vládne nariadenie č. 70/1968 Z. z. z 1968 z 13. júna 1968.

8 Porov. D. Dzurovčin, Schematizmus prešovskej gréckokatolíckej metropolie, Prešov [n.o.], s. 29.

9 Porov. M. Hospodár, M. Rozkoš, Košický exarchát. Košice exarchát, Košice 2005, s. 12-13.

10 Porov. D. Dzurovčin, Schematizmus prešouskej gréckokatolíckej metropolie, Prešov [n.o.], s. 38.

11 Trebnik obsahuje slávenia svätých tajomstiev krstu, myropomazania, svätej spovede, sobáša a pomazanie chorých svätým olejom. Okrem toho obsahuje aj potrebné požehnania. 
trebniky, ktoré Arcibiskupský úrad v rámci starostlivosti o hodnotné staré bohoslužobné knihy dal priniest’ do Prešova.

Pred skúmaním ohladom iniciácie sme preskúmali známy Trebnik Petra Mohylu. Bol vydaný v Kijeve v roku 1646. Po udelení myropomazania trebnik uvádza obsiahlu rubriku. Rubrika sa vzt’ahuje na pokrsteného v dospelom veku a pokrsteného ako diet'a:

Treba vediet', že ak bude liturgia, pokrstené diet’a nesú v sprievode so sviečkami pred darmi na velkkom vchode. Ak je pokrstený dospelý, so sviečkami v každej ruke, sám ide na vel'kom vchode pred darmi. Sväté tajomstvá Krista, Pána a nášho Boha, rovnako prijímajú novopokrstení či už je to diet’a, alebo je to dospelý. Po prepustení novopokrstení so sviečkami v rukách a v sprievode svojich príbuzných odchádzajú domov. Po krste novopokrstený je osem dní privádzaný do cerkvi, kde s horiacimi sviečkami v rukách sa zúčastňuje na večierni, na utierni i na liturgii ${ }^{12}$.

Trebnik z Torysiek z roku 1682 obsahuje presne doslova uvedenú rubriku $^{13}$. Na rozdiel od tohto Trebnika trebnik z Počajeva z roku 1741, hoci bol vydaný v blízkom období, uvedenú rubriku už neobsahuje ${ }^{14}$. Eucholigion si jest' Trebnik z roku 1719 nájdený na smetisku obsahuje ten istý predpis $^{15}$.

Uvedené, Trebniky okrem Mohylovho trebnika, boli používané v Prešovskej eparchii. Môžeme preto predpokladat', že neofytom sa eucharistia podávala.

O to viac, že synoda v Zamošči v roku 1720 vydala dokument, ktorým nariad'uje pre duchovenstvo odstránit’ zvyk podávania eucharistie neofytom $^{16}$. Rozhodnutia snemu prebrala aj mukačevská eparchia a táto prax zostala aj v prešovskej eparchii erigovanej z mukačevskej eparchie.

Významným zdrojom k podávaniu eucharistie pri krste je kánonická vizitácia Františka Barkóczyho, jágerského katolíckeho biskupa latinského obradu. V roku 1749 vizitoval farnosti byzantského obradu, v ktorom

12 Trebnik Petra Mohyli, Kiev 1646.

13 Porov. Trebnik, Lvov 1682.

14 Trebnik, Počajev 1741.

15 Euchologion Si Jest' Trebnik, Lvov 1719, s. 24.

16 J. Bilanych, Synodus Zamostiana an. 1720, Romae 1960, s. 56, b. 8, s. 58, b. 3 . 
s nepochopením odmieta liturgickú prax podávania eucharistie detom po krste $^{17}$.

\section{Iniciácia $v$ nových trebnikoch}

Počas pražskej jari v roku 1968 Kongregácia pre východné Cirkvi zaslala na farnosti Prešovskej eparchie cirkevnoslovanský Trebnik oo. baziliánov vydaným v Žovkve v roku 1926, v ktorom v rubrikách pri krste sa tiež nespomína prijímanie neofitov.

\section{Slovenské trebniky}

V Prešovskom biskupstve sa po obnovení jej činnosti v roku 1968 vynorila požiadavka slávenia svätých tajomstiev v slovenskom jazyku. Prešovské biskupstvo reagovalo na túto požiadavku postupným vydaním trebnikov v slovenskom jazyku:

- Schválený text obradov sv. krstu, myropomazania a úvodu, 1970;

- Vysluhovanie sviatostí a svätenín, 1973;

- Sviatosti a sväteniny, 1987;

- Dočasný preklad trebnika, $1996^{18}$.

Malý trebnik je oficiálny a schválený preklad z cirkevnoslovanského textu Malého trenika z roku 1950. Preklad Malého trebnika na Slovensku bol uvedený do liturgickej praxe od 1. októbra $2006^{19}$.

Ani v slovenských prekladoch nie je žiadna zmienka o podávaní eucharistie po krste.

V eparchiách, ktoré vznikli z mukačevskej eparchie aj s jej liturgickou praxou je prax rozdielna. V Metropolii Hajdúdorog sa tretie iniciačné tajomstvo nepodáva. V Mukačevskej eparchii na Ukrajine tak isto sa tretie iniciačné tajomstvo nepodáva. V A poštolskom exarcháte v Srbsku a v Čiernej Hore eucharistia ako tretie iniciačné tajomstvo sa nepodáva, i ked' vel'mi

\footnotetext{
17 T. Véghseő, J. Nyírán, A Barkóczy instrukció. Kéziratos szerkönyvek, Nyíregyháza 2012, s. $15-18$.

18 Archív ABÚ Prešov, č.j. 2641/96.

19 K jednotlivým vydaniam upustíme od komentára nakolko nie sú témou prednášky.
} 
zriedkavo kňazi podajú sväté prijímanie detom. Eucharistia sa nepodáva ani Pražskom apoštolskom exarcháte, ktoré vzniklo z Prešovskej eparchie v Českej republike ${ }^{20}$.

V Pitsburgsej metropolii sa eucharistia ako iniciačné sväté tajomstvo začalo podávat’ už 70-tych rokoch dvadsiateho storočia.

\section{Začiatky úplnej iniciácie na farnostiach}

Na Slovensku úplná iniciácia sa začala objavovat’ po roku 1989. Prvé správy o krste udelenom ponorením a následne aj udelením Eucharistie sa objavili v neokatechumenátnom hnutí. Kňazi, ktorí patrili do tohto hnutia, začali ho vel'mi opatrne praktizovat' aj vo svojich farnostiach. I ked' to nebola ešte oficiálna prax zo strany vedenia eparchie, prax podávania eucharistie sa stávala známou a praktizovanou, na základe Inštrukcie vydanej Kongregáciou pre východné Cirkvi. Bratislavská farnost’ slávenie všetkých troch iniciačných tajomstiev uviedla do života, čím sa stala akoby priekopníkom úplnej iniciácie a zároveň aj 'laboratóriom' pre ostatné farnosti.

Po schválení slovenského prekladu Malého trebnika ${ }^{21}$ sa stal aktuálnym krst ponorením a podávanie eucharistie.

V roku 1997 vznikol Košický apoštolský exarchát ${ }^{22}$ a Prešovské biskupstvo v nových hraniciach. Kým na území prešovského biskupstva sa eucharistia po krste nezačala podávat', košický exarcha pri krstoch, ktoré udel'oval v rámci božskej liturgie, podal aj eucharistiu. Následne vydal aj smernicu, na základe ktorej sa eucharistia môže udelit’ v prípade, že sa krst slávi spolu s božskou liturgiou, ale d’al'šie udel'ovania je ešte v rovine diskusie ${ }^{23}$.

S otázkou celoplošného podávania eucharistie ako tretieho iniciačného tajomstva sa zaoberala liturgická komisia.

20 Pražský exarchát vyhlásil 13. marca 1996 svätý pápež Ján Pavol II, in: D. Dzurovčin, Schematizmus prešovskej gréckokatolíckej metropolie, Prešov [n.o.], s. 29.

21 Slovenský preklad Malého trebnika bol schválený 10. januára 2006. Slávenia sa podla neho začali 1. októbra 2006.

22 Porov. M. Hospodár, M. Rozkoš, Košický exarchát. Košice exarchát, s. 12-13.

23 Porov. M. Hospodár, Iniciačné sviatosti v košickom apoštolskom exarcháte, in: Vysluhovanie sviatostí podl'a Malého trebnika (Recenzione ruthena), Prešov 2007, s. 166-171. 
V roku 2008 bola založená Prešovská gréckokatolícka metropolia ${ }^{24}$. Krátko po ustanovení metropolie bola ustanovená Rada hierarchov. K prvým otázkam, ktorými sa Rada hierarchov bola aj otázka krstu ponorením a otázka eucharistie ako tretieho iniciačného tajomstva.

V bratislavskej eparchii hned' po jej vzniku 2008 na podnet eparchu ${ }^{25} \mathrm{sa}$ podávanie eucharistie hned' po krste uviedlo do života vo všetkých jej farnostiach Rada hierarchov si naplno uvedomila požiadavku dekrétu Orientalium ecclesiarum (6) o návrate starootcovským tradíciám ako aj požiadavku Codex canonum Ecclesiarum Orientalium [CCEO] kán. 710 (1990), KKC 1233 (1992) Inštrukciu na vykonávanie bohoslužobných predpisov Kódexu kánonov východných cirkví (1996). Otázkou o uvedení tretieho iniciačného tajomstva do praxe sa zaoberala aj prvá eparchiálna synoda (2015-2017), ktorá sa vyslovila za prax krstu ponorením aj podania eucharistie po krste.

\section{Rozhodnutie Rady hierarchov}

Po týchto predchádzajúcich udalostiach Rada hierarchov na svojom zasadnutí v máji roku 2017 sa rozhodla, že od 1. septembra 2017 sa tretie iniciačné tajomstvo začne podávat’ na území celej metropolie.

Metropolita Ján Babjak uviedol túto prax pastierskym listom k veriacim, ktorým vysvetlil význam podania eucharistie po krste. Dôrazne upozornil, že prax podávania eucharistie sa nevzṫahuje na deti latinského obradu. Ak by boli na byzantskej liturgii kňaz im nesmie podat' eucharistiu. Ak však na svätej omši sú prítomné deti byzantského obradu, kňaz nesmie odmietnut podat' im eucharistiu. Veriaci vo farnostiach na túto udalost' pripravovali kňazi siedmymi katechézami na témy:

1. sväté tajomstvá v živote veriaceho človeka;

2. krestanská iniciácia - jednota a nedelitel'nost';

3. charakteristické znaky a symboly vysluhovania tajomstiev krestanskej iniciácie v byzantskom obrade;

24 Metropoliu založil pápež Benedikt XVI. 20. januára 2008 bulou Spiritali emolumento, in: D. Dzurovčin, Schematizmus prešovskej gréckokatolíckej metropolie, Prešov [n.o.], s. 38.

25 Eparcha je Mons. Peter Rusnák, predtým bratislavský farár, ktorý už počas svojej kňazskej činnosti krstil ponorením a podáva krstencom aj eucharistiu. 
4. krst brána do nového života;

5. myropomazanie ako samostatné tajomstvo a súčast’ krest’anskej iniciácie;

6. eucharistia - s dôrazom na podávanie pre deti;

7. krestanská výchova v rodine.

Okrem katechéz sa pamätalo aj na smernice pre kňazov (9 bodov), špeciálne smernice pre kňazov ohl'adom prípravy na slávnost' svätého tajomstva zmierenia ( 18 bodov), smernice pre rodičov ( 18 bodov) a smernice pre katechétov (9 bodov).

Uvádzame metropolitné Smernice kňazom, ohladom podávania eucharistie nemluvňatám a malým detom:

1. Detom po krste a myropomazaní, ako aj osobám pozbaveným užívania rozumu možno podávat’ presvätú Eucharistiu.

2. Pokial' ide o prijímanie nemluvniat a malých detí, ten, kto podáva presvätú Eucharistiu, musí pamätat’ na to, že je nevyhnutnostou spočiatku podávat' diet'at'u Eucharistiu iba pod spôsobom vína, až neskôr, ked' už celkom prirodzene prijíma pevnú stravu (reálne okolo druhého roka veku), prejst’ opatrne aj na podávanie pod spôsobom chleba. Čiže sa musí brat' do úvahy skutočnost', či je diet’a schopné Eucharistiu požit'. V prípade akýchkolvek nejasností a pochybností nech kňaz podáva iba Kristovu krv.

3. Diet’a, ktoré ešte neprijalo sviatost’ zmierenia a pokánia, spravidla nesmie pristupovat' $\mathrm{k}$ prijatiu Eucharistie samo, ale iba v sprievode jedného z rodičov alebo vhodnej dospelej osoby (15), ktorá svojou prítomnostou vydáva pred kňazom svedectvo, že dieta môže prijat’ Eucharistiu. Kňaz môže podat’ Eucharistiu dietat’u bez doprovodu, ak objektívne pre.

4. Malé deti rodičia privádzajú na prijímanie Eucharistie zvyčajne na rukách alebo ich vedú za ruku.

5. Odporúča sa, aby kňaz podal Eucharistiu najprv rodičovi a až potom diet’at'u.

6. Rodičov treba viest' $\mathrm{k}$ tomu, aby aj oni sami hodne prijímali Eucharistiu, ak je to možné.

7. Treba byt' citlivý na výber vína na Eucharistiu, aby bolo prírodné, čisté, hroznové a bez prísad. Víno má byt’ dobrej kvality, má mat' príjemnú vôňu a chut', nemá byt' príliš kyslé. Odporúča sa, aby to bolo červené víno.

8. Pokial' diet’a nechce prijat’ sväté prijímanie (hádže sa, plače), netreba mu ho nasilu podávat'. 
9. Hoci malé deti neviaže povinnosṫ zvláštnej prípravy na prijatie Eucharistie ani eucharistický pôst, predsa treba, aby rodičia svoje deti k týmto veciam primerane ich schopnostiam a veku postupne viedli a navykali ${ }^{26}$.

\section{Záver}

Slávenie iniciačných svätých tajomstiev prešlo v Prešovskom biskupstve a od ustanovenia aj v Prešovskej metropolii zložitejším aktualizačným vývojom. Jedna $\mathrm{z}$ hlavných príčin prečo bol návrat $\mathrm{k}$ jednému a nedelitel'nému sláveniu iniciačných svätých tajomstiev zložitejší, bola skutočnost̉ likvidácie Prešovskej gréckokatolíckej eparchie politickou mocou v roku 1950. Gréckokatolícki biskupi, kňazi i veriaci boli vo väzení, alebo vysídlení do českého pohraničia štátu, čo trvalo 18 rokov. Len vel'mi málo gréckokatolíkov bolo informovaných o priebehu Druhého vatikánskeho koncilu a jeho rozhodnutiach aj o východných katolíckych cirkvách v dekréte Orientalium ecclesiarum.

Po obnove činnosti Gréckokatolíckej cirkvi v roku 1968 bolo nutné zabezpečit základnú štruktúru cirkvi a jej pôsobenie, čo v časoch normalizácie nebolo jednoduché. Vol'ná činnost’ sa začala v po revolúcii v roku 1989. Od toho času mohli nastúpit všetky potrebné kapacity aj k uskutočňovaniu požiadaviek Koncilu, právneho poriadku na základe CCEO ako aj Inštrukciou na aplikáciu bohoslužobných predpisov Kódexu kánonov východných cirkví, vydanou Kongregáciou pre východné cirkvi.

Veriaci l’ud Gréckokatolíckej metropolie - až na malé výnimky - prijal slávenie iniciačných svätých tajomstiev v jednom slávení, teda aj s podaním eucharistie s pochopením, čo je zárukou toho, že budúcnosti tento krok bude trvalo prinášat svoje duchovné ovocie.

26 Porov. P. Tirpák, M. Ilko, Podávanie Eucharistie detom a nemluvňatám po krste, Prešov 2017, s. 22. 


\section{Streszczenie}

\section{Petna inicjacja w Greckokatolickiej Metropolii Preszowskiej}

Inicjacja jest podstawowym elementem liturgicznej praktyki w Kościele. W ciągu dziejów różne rzeczy wpływały na jej rozwój i formowanie się. W ramach tego rozwoju odmienny porządek inicjacji ukształtował się w Kościele łacińskim i bizantyjskim. Zwłaszcza we wschodnich Kościołach różnych obrządków zjednoczonych z Rzymem rozwój obrzędu inicjacji był ciekawy. Warto tutaj wspomnieć o metropolii preszowskiej obrządku bizantyjskiego na Słowacji, która w 2018 roku obchodziła dwusetną rocznicę swego powstania. W studium został przedstawiony rozwój obrzędu inicjacji w preszowskiej metropolii. 